\title{
PERBEDAAN GENDER DALAM STRES YANG DIRASAKAN DI KALANGAN DEWASA SEBELUM DAN SESUDAH KONSELING
}

\author{
Gilang Permana \\ Sekolah Tinggi Ilmu Sosial Dan Ilmu Politik Guna Nusantara \\ Email: gilang01@gmail.com
}

\begin{abstract}
Abstrak
Tujuan dari penelitian ini adalah, untuk mengetahui perbedaan gender dalam stres yang dirasakan di kalangan dewasa muda sebelum dan sesudah konseling. Artikel saat ini menyajikan perbedaan rata-rata di antara kedua gender yang merasakan stres sebelum dan sesudah konseling. Untuk melakukan penelitian, sampel 120 dewasa muda yang termasuk dalam kelompok usia 2040 tahun dipilih. Untuk mengukur tingkat stres di antara orang dewasa muda skala stres yang dirasakan yang dikembangkan oleh Cohen (1983) digunakan. Hasil penelitian menunjukkan bahwa tidak ada perbedaan yang signifikan antara jenis kelamin sebelum dan sesudah konseling. Namun, perbedaan rata-rata yang diamati antara jenis kelamin yang menggambarkan wanita memiliki tingkat stres yang dirasakan lebih tinggi dibandingkan dengan pria sebelum dan sesudah konseling. Oleh karena itu, terbukti bahwa teknik konseling efektif dalam mengurangi stres dan meningkatkan strategi koping yang lebih baik di kalangan dewasa muda.

Kata kunci: Konseling, Persepsi Stres, Gender, Stres Keuangan
\end{abstract}

\begin{abstract}
The aim of this study was to determine gender differences in the stress felt among young adults before and after counseling. The current article presents the mean difference between the genders who experienced stress before and after counseling. To conduct the study, a sample of 120 young adults belonging to the 20-40 year age group was selected. To measure stress levels among young adults the perceived stress scale developed by Cohen (1983) was used. The results showed that there was no significant difference between the sexes before and after counseling. However, the mean difference observed between the sexes depicts women as having higher levels of perceived stress than men before and after counseling. Therefore, it has been shown that counseling techniques are effective in reducing stress and promoting better coping strategies among young adults.
\end{abstract}

Keywords: Counseling, Perception of Stress, Gender, Financial Stress

\section{A. PENGANTAR}

Dewasa muda mencoba mengembangkan keterampilan baru, atau belajar untuk mengatasi pengalaman baru dalam kehidupan sehari-hari mereka. Transisi yang berhasil akan meningkatkan kesediaan dewasa muda untuk menghadapi tantangan JURNAL PAPATUNG: Vol. 2 No. 1 Tahun 2019 ISSN: 2715-0186 
baru dan menerima perubahan dalam hidup. Ketidakmampuan atau transisi yang tidak berhasil sering menyebabkan stres di kalangan dewasa muda yang membatasi kinerja mereka di tempat kerja dan juga dengan keluarga. Stres bersifat dinamis yang membebani penyesuaian fisik dan psikologis seseorang dengan lingkungannya, menyebabkan kepribadian yang terganggu serta penyakit fisik dan mental. Sumber stres berbeda untuk setiap orang, mungkin karena dunia kompetitif di mana mereka selalu diawasi dengan cermat untuk dicapai sehubungan dengan pendidikan tinggi, lingkungan profesional yang tidak dapat diprediksi, kompensasi berat dengan ekspektasi besar bagi karyawan, dll. Selain itu, orang dewasa muda juga menghadapi Peran dan tanggung jawab baru dalam kehidupan pribadi sebagai mitra, orang tua, dan pengelolaan keuangan akan sering menimbulkan stres di kalangan dewasa muda. Stres memiliki efek langsung pada suasana hati dan meningkatkan gangguan tidur, lekas marah, dan perubahan kognitif seperti gangguan konsentrasi yang mempengaruhi kesehatan fisik dan mental di antara orang dewasa muda yang menyebabkan kecemasan, depresi, dan demensia. Sebuah studi yang dilakukan oleh ICICI Lombard, (2017) mengungkapkan bahwa sekitar 65\% responden pada kelompok usia 22-25 menunjukkan tanda-tanda depresi, dibandingkan dengan $60 \%$ pada kelompok usia $26-$ 30 dan 55\% pada kelompok usia 31 tahun. tahun ke atas. Studi tersebut juga menemukan bahwa tingkat pendapatan yang lebih rendah adalah sumber utama stres seperti kurang tidur; Sebanyak 64\% responden kurang tidur dengan waktu tidur kurang dari 7-8 jam. Sekitar 55\% responden mengatakan itu adalah masalah terkait pendapatan yang menyebabkan mereka stres maksimum dalam kehidupan profesional mereka.

Laki-laki dan perempuan memandang stres secara berbeda di mana perempuan memandang stres tinggi karena jam kerja yang panjang dan terkait keluarga, JURNAL PAPATUNG: Vol. 2 No. 1 Tahun 2019 ISSN: 2715-0186 
sedangkan laki-laki memandang stres berdasarkan tekanan keuangan dan pekerjaan. Wanita yang bekerja lebih dari 60 jam seminggu memiliki persepsi kontrol yang lebih rendah dan melaporkan tingkat stres yang lebih tinggi daripada wanita yang bekerja dengan jam kerja lebih sedikit. Namun, laki-laki yang bekerja lebih dari 60 jam melaporkan peningkatan tingkat kontrol (Tytherliegh et al. 2007). Untuk mengatasi masalah stres yang dirasakan di kalangan dewasa muda, diidentifikasi bahwa konseling akan menjadi metode yang efektif dalam membantu dewasa muda mengelola stres mereka. Konseling merupakan strategi intervensi yang dapat memfasilitasi dewasa muda dalam mengurangi stres dan kecemasan, serta meningkatkan kesejahteraannya. Hal ini dilakukan melalui keterampilan terapeutik yang dibina oleh konselor, seperti hadir pada saat bersama klien, partisipasi dalam mendengarkan secara aktif, membina hubungan terapeutik yang kuat, dan mencerminkan empati terhadap perasaan klien, semuanya dengan cara yang tidak menghakimi (Kaplan, Tarvydas, \& Gladding, 2014). Konseling individu memiliki manfaat yang jelas bagi kesejahteraan psikologis karyawan (Renolds, 1997). Peningkatan partisipasi karyawan dan acara pelatihan mengurangi stres karyawan. Manajemen stres dan teknik relaksasi membantu individu untuk menghadapi situasi hidup mereka dan meningkatkan kesejahteraan mereka. Oleh karena itu, penelitian kali ini bertujuan untuk memahami perbedaan gender dalam stres yang dirasakan di kalangan remaja sebelum dan sesudah konseling untuk melihat efektivitas konseling.

\section{B. PEMBAHASAN}

Orang dewasa muda yang termasuk dalam kelompok usia 20-40 tahun dari kota kembar Hyderabad dan Secunderabadwere dipilih untuk penelitian ini. Teknik pengambilan sampel purposif diadopsi untuk penelitian ini (dewasa muda yang telah JURNAL PAPATUNG: Vol. 2 No. 1 Tahun 2019 ISSN: 2715-0186 
mendekati pusat konseling untuk mencari bantuan dari para profesional untuk stres yang dirasakan mereka adalah bagian dari penelitian). Sampel yang sama dari 60 pria dan 60 wanita dipilih untuk penelitian ini. Untuk mengetahui stres yang dirasakan di kalangan dewasa muda, peneliti menggunakan "skala stres yang dirasakan" yang dikembangkan oleh Sheldon Cohen (1983). Konsistensi internal PSS koefisien Cronbach $\alpha$ (keandalan) skala adalah 0,85. Ini menilai sejauh mana peserta mengevaluasi kehidupan mereka sebagai stres selama sebulan terakhir. Data tentang skala stres yang dirasakan dikumpulkan dalam dua tahap, satu sebelum sesi konseling dan yang lainnya setelah konseling. Data yang terkumpul diberi kode dan dianalisis menggunakan frekuensi, persentase, dan uji-t berpasangan.

\section{HASIL}

Tabel 1: Perbedaan Gender dalam Persepsi Stres sebelum Konseling (Pre-Test)

\begin{tabular}{|c|c|c|c|c|c|c|}
\hline \multirow{2}{*}{$\begin{array}{c}\text { Stres yang } \\
\text { dirasakan }\end{array}$} & \multicolumn{2}{|c|}{ Men } & \multicolumn{2}{c|}{ Wanita } & \multirow{2}{*}{ nilai-t } & Kemungkinan \\
\cline { 2 - 7 } & Berarti & SD & Berarti & SD & & \\
\cline { 2 - 7 } & 15.8 & 4.16 & 17.23 & 4.63 & 1.78 NS & 0.07 \\
\hline
\end{tabular}

Keterangan: * Signifikansi pada $(\mathrm{P}<0,05),{ }^{* *}$ Significance at $(\mathrm{P}<0,05)$, NS- Not

\section{Significant}

Tabel di atas menyajikan perbedaan gender antara pria dan wanita berdasarkan stres yang mereka rasakan sebelum konseling. Ini jelas menggambarkan bahwa tidak ada perbedaan yang signifikan antara kedua jenis kelamin sehubungan dengan stres yang dirasakan sebelum konseling. Temuan penelitian ini sejalan dengan penelitian yang dilakukan oleh Ghaderi et al. (2009) yang menyimpulkan bahwa tidak ada perbedaan jenis kelamin yang signifikan pada stres, namun terdapat perbedaan antaraberarti banyak pria dan wanita. Skor rata-rata yang tinggi dengan mengacu pada stres yang dirasakan diamati pada wanita jika dibandingkan dengan pria. 
Skor rata-rata yang tinggi pada stres yang dirasakan menunjukkan bahwa perempuan lebih emosional, vokal dan terpengaruh oleh stres yang terkait dengan keluarga, pendidikan, status perkawinan, anak, pekerjaan dan situasi kehidupan. Di sisi lain, stres pria dikaitkan dengan karier, keuangan, pekerjaan, dan keluarga. Ini mungkin juga karena wanita lebih peka terhadap dunia di sekitar mereka dan bereaksi lebih emosional daripada berfokus pada solusi. Baik pria maupun wanita melaporkan stres yang substansial sebagai tanggapan atas masalah-masalah dengan situasi kehidupan. Ini mungkin karena ekspektasi masyarakat untuk kedua jenis kelamin berbeda-beda dan mengakibatkan kesejahteraan mereka. Pria mendapat skor lebih rendah dibandingkan dengan wanita dengan stres yang dirasakan hal ini mungkin karena pria takut mengungkapkan atau sangat tidak menyadari perasaan mereka (Hogan, 2002). Ini mungkin juga karena pria kurang menekankan pada kebutuhan untuk mengelola stres mereka daripada wanita. Penelitian lain yang mendukung hasil yang dilakukan Pathak, Mitali (2011) mengungkapkan bahwa secara umum perempuan mempersepsikan situasi yang lebih stres dibandingkan dengan laki-laki dan menggunakan strategi koping yang berfokus pada emosi. Di sisi lain, laki-laki berusaha mengontrol penyebab situasi terlebih dahulu daripada memberikan reaksi berdasarkan emosi.

Tabel 2: Perbedaan Gender dalam Persepsi Stres setelah Konseling (Post-Test)

\begin{tabular}{|l|c|c|c|c|c|c|}
\hline \multirow{2}{*}{$\begin{array}{l}\text { Stres yang } \\
\text { dirasakan }\end{array}$} & \multicolumn{2}{|c|}{ Men } & \multicolumn{2}{c|}{ Wanita } & nilai-t & \multirow{2}{*}{ Kemungkinan } \\
\cline { 2 - 5 } & Berarti & SD & Berarti & SD & & \\
\cline { 2 - 5 } & 10.85 & 4.22 & 12.20 & 4.71 & -1.65 NS & 0.10 \\
\hline
\end{tabular}

Keterangan: * Signifikansi pada $(\mathrm{P}<0,05),{ }^{* *}$ Significance at $(\mathrm{P}<0,05)$, NS- Not

\section{Significant}


Tabel di atas menggambarkan perbedaan gender sehubungan dengan stres yang dirasakan setelah konseling. Hal ini terbukti dari tabel bahwa tidak ada perbedaan signifikan yang ditemukan antara pria dan wanita sehubungan dengan stres yang dirasakan setelah konseling. Artinya baik laki-laki maupun perempuan mengalami penurunan tingkat stres setelah konseling dibandingkan sebelum konseling. Hasil tersebut sejalan dengan penelitian yang dilakukan oleh Dyson dan spirit, (2006) mengungkapkan bahwa tidak ada perbedaan gender dalam mengatasi stres. Namun, ada perbedaan yang ditemukan pada nilai rata-rata mereka. Pria memiliki skor ratarata yang rendah pada stres yang dirasakan dibandingkan dengan wanita setelah konseling.

Skor rata-rata yang rendah pada stres yang dirasakan mungkin karena laki-laki dapat merespons konseling dengan cepat dan menggunakan lebih banyak strategi yang berfokus pada pemecahan masalah untuk mengatasinya, sedangkan wanita menggunakan strategi yang berfokus pada emosi untuk mengatasi yang membutuhkan durasi yang mempertimbangkan untuk mengatasinya. Wanita memiliki skor rata-rata yang lebih tinggi daripada pria setelah konseling, hal ini mungkin disebabkan oleh stres akut dan kronis yang dialami wanita. Namun, perbedaan antara kedua jenis kelamin tetap ada bahkan sebelum konseling. Penelitian MoomuangNikom, 2005 menunjukkan bahwa ada hubungan terbalik antara peningkatan pengalaman stres yang dilaporkan dan perilaku yang meningkatkan kesehatan, sehingga pria muda yang terlibat dalam perilaku peningkatan kesehatan yang positif, olahraga, ekspresi nutrisi yang baik dari emosi dan kolaborasi sosial kecil kemungkinannya untuk melaporkan insiden dampak yang tinggi pada sumber stres.

\section{KESIMPULAN}

JURNAL PAPATUNG: Vol. 2 No. 1 Tahun 2019

ISSN: 2715-0186 
Temuan penelitian mengungkapkan bahwa teknik manajemen stres, terapi relaksasi dan pelatihan berorientasi tujuan telah meningkatkan orang dewasa muda dari kedua jenis kelamin untuk mengatasi stres. Perbedaan mean secara jelas menggambarkan bahwa terdapat perbedaan mean yang signifikan antara jenis kelamin sebelum dan sesudah konseling. Secara jelas disebutkan bahwa wanita merasakan tingkat stres yang tinggi dibandingkan pria. Intervensi untuk wanita mungkin fokus pada peningkatan penggunaan adaptifstrategi seperti berdoa dan berbicara dengan teman dan keluarga, sementara intervensi untuk pria dapat memperkenalkan penggunaan strategi koping adaptif seperti olahraga dan secara aktif melawan penyebab stres.

\section{DAFTAR PUSTAKA}

Dyson, R., \& Renk, K. (2006). Adaptasi mahasiswa baru ke Kehidupan Universitas; Gejala Depresif, Stres dan Coping. Jurnal Psikologi Klinis, 62 (10), 1231-1244.

Ghaderi, A.R., Kumar, V. dan Kumar S. (2009). Depresi, kecemasan dan stres di antara siswa India dan Iran, J. Indian Academy Appl. Psychol., 35 (1): 33-37.

Hogan, J. M., Carlson, J. G., \& Dua, J. (2002). Stresor dan reaksi stres di antara personel universitas. Jurnal Internasional Manajemen Stres, 9, 289-310.

BHAT, SUHAIL AHMAD, dan SHAWKAT AHMAD SHAH. "Belas kasihan diri dan kesehatan mental: sebuah studi tentang orang dewasa muda." DAMPAK: Jurnal Penelitian Internasional dalam Ilmu Terapan, Alam dan Sosial 3.4 (2015): 49-54.

https://timesofindia.indiatimes.com/business/india-business/65-millennials-show-early-signs-ofdepression-icici-lombard-survey/articleshow/58229293.cms

Kaplan, D. M., Tarvydas, V. M., \& Gladding, S. T. (2014). 20/20: Visi untuk Masa Depan Konseling: Definisi Konsensus Baru tentang Konseling. Jurnal Konseling \& Pengembangan, 92 (3), 366-372.

MoomuangNikom, 2005; "Manajemen Stres dan Perilaku Promosi Kesehatan pada Pria Muda dalam Pengaturan Pendidikan Tersier", Tesis, Pp .: 7,162,185.

T Murry, Renabeni dan Pujar, Lata, Preferensi Jodoh Berbasis Gender di Kalangan Dewasa (6 Maret 2018). DAMPAK: Jurnal Penelitian Internasional dalam Ilmu Terapan, Alam dan Sosial, Vol. 6, Edisi 2, Feb 2018, 27-32.

Pathak, Mitali. (2011). Memanfaatkan Manajemen Stres Tingkat Stres: Sebuah Perspektif Gender. Jurnal Internasional Manajemen Stres, Vol. 15 (1), hlm 94-115.

JURNAL PAPATUNG: Vol. 2 No. 1 Tahun 2019

ISSN: 2715-0186 
Renolds S., 1997, "Kesejahteraan Psikologis di Tempat Kerja: Apakah Pencegahan Lebih Baik daripada Pengobatan", Jurnal Penelitian Psiko somatik, 43, Pp .: 93-102.

Shah, M., Hasan, S., Malik, S., dan Sreeramareedy, C.T. (2010). Stres yang dirasakan, sumber dan tingkat keparahan stres di antara mahasiswa kedokteran. Dalam A Pakistan Medical School, BMC Medical Edu., 10 (2): 1-8.

Tytherleigh MY, Webb C, Cooper C, Ricketts C (2005) Stres Pekerjaan di Institusi Pendidikan Tinggi Inggris: Sebuah studi komparatif dari semua kategori staf. Penelitian dan Pengembangan Pendidikan Tinggi 24 (1): 41-61. 